\title{
Macro-Economic Variables and Stock Market: are they Co-integrated? - A Study on NSE India
}

\section{OPEN ACCESS}

Manuscript ID:

COM-2021-09023740

Volume: 9

Issue: 2

Month: April

Year: 2021

E-ISSN: 2582-6190

Received: 20.01.2021

Accepted: 05.03.2021

Published: 01.04.2021

Citation:

Sahoo, Aditya Prasad.

"Macro-Economic

Variables and Stock

Market: are they Co-

Integrated? - A Study

on NSE India." ComFin

Research, vol. 9, no. 2,

2021, pp. 25-30.

DOI:

https://doi.org/10.34293/

commerce.v9i2.3740

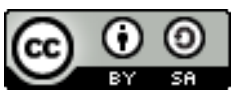

This work is licensed under a Creative Commons Attribution-ShareAlike 4.0 International License

\author{
Aditya Prasad Sahoo \\ Ph D Research Scholar, KIIT School of Management, Bhubaneswar, Odisha, India \\ https://orcid.org/0000-0003-4399-2604
}

\begin{abstract}
The stock market acts as a barometer for the economy. Stock Market Performance and Economic Growth go in hand in hand in the case of the Indian economy. While considering Indian economic growth, the stock market performance plays an essential role. The period of study ranges from 2000 to 2017. The tools used for the study are the ADF unit root test and Johansen co-integration test. The study concludes that Gross domestic product, FDI, Crude oil price, Inflation and Real interest rate have a significant relationship with the NSE stock market for the study period.
\end{abstract}

Keywords: ADF test, Co-integration, Economy, Macroeconomic variables, NSE

\section{Introduction}

The stock market does the job of collecting funds in capital markets. The intermediaries for the fund flow in the stock market are financial institutions like life insurance companies, mutual funds, pension funds and foreign institutional investors. Generally, the performance of the stock market is detected as a measuring instrument for the development of the Indian economy. The bullish market indicates the growth in the economy, whereas Bearish Market shows the decline in the economy. The stock market allocates capital to corporate sectors which will have an impact on real economic activity. When firm borrowings are more than the return on investment, then the economic growth will be declining. Thus, the stock market and economic growth are interrelated with one another. Organized and active stock markets can change the form of demand for money $\&$ thus supporting the development of the economy.

\section{Review of Literature}

Naka, et. al. (1998) analyzed relationships among selected macroeconomic variables and the Indian stock market. By employing a vector error correction model, the Analysis finds that three long-term equilibrium relationships exist among these variables. The results suggest that domestic inflation is the most severe deterrent to Indian stock market performance, and domestic output growth is its predominant driving force.

Pethe and Karnik (2000), using Indian data for April 1992 to December 1997, attempts to find how stock price indices are affected by and affect other crucial macroeconomic variables in India. The study, of course, avers that in the absence of co-integration, it is not legitimate to test for causality between a pair of variables. It does so given the importance of the relation between the state of the economy and stock markets.

Bhattacharya and Mukherjee (2002) investigated the nature of the causal relationship between the BSE Sensitive Index and the five macroeconomic aggregates in India (i.e., IIP, money supply, national income, interest rate and 
inflation rate) using monthly data for the period 1992- 93 to 2000. Their major findings suggested no causal linkage between stock prices and money supply, national income and interest rate while IIP lead the stock price, and there was two-way causation between stock price and inflation rate.

Mishra (2004) by using monthly data for period 1992 to 2002, examined relationship between stock market and foreign exchange markets using Granger causality test \& Vector Auto Regression technique study suggested that there is no Granger causality between exchange rate return \& stock return.

Kaur (2009) In this research thesis, an attempt has been made to explore the causal relation between BSE SENSEX and some macro-economic variables by using correlation, descriptive statistics, unit root stationary tests and Granger causality. Annual data has been used from 1950 to 2006 for all the variables, like, SENSEX, per capita gross national product (GNP), forex reserves, gross domestic product (GDP), bank rate, wholesale price index (WPI), gross domestic capital formation, domestic savings, broad money. Econometric techniques like unit root tests have been done to check out the stationarity. Finally, Granger causality has been applied to study the causal relationship between them and results that have come out are mixed.

Chellasamy (2013) analyzed the effects on rupee depreciation against the dollar, covering the area of currency growth, foreign investment, and macroeconomic factors that affected Indian currency during study period from 1989-1970 to 2012-2013.

\section{Statement of the Problem}

The study examines whether there is any statistically significant relationship between the key parameters of performance of NSE on economic growth. The stock market performance has a positive impact on economic development. There will be a dilemma existing among the investors and economists whether the stock market influences the economic growth or economic growth shows the impact on the stock market performance. Considering this dilemma, the study is being made to reflect the impact of NSE stock market performance on the Indian economic growth. This study is carried out from 2000 to 2017.

\section{Objective of the Study}

1. To find out the co-integration between macroeconomic variables and the stock market.

2. To see whether any relationship exist between economic variables and the performance of the stock market.

\section{Hypothesis of the Study}

H0: There is no stationarity exists between macroeconomic variables and Stock Market.

H1: Co-integration exists between GDP and stock market performance.

H2: Co-integration exists between FDI and stock market performance.

H3: Co-integration exists between crude oil price and the stock market.

H4: Co-integration exists between inflation and stock market performance.

H5: Co-integration exists between the interest rate and the stock market.

\section{Research Methodology}

The sampling used for this study is the Purposive sampling method. The data are collected based on the purpose for the data to be collected and the data relevant for the study and the availability of the data. The data used for the study is secondary and it is yearly data and collected from the NSE website and World Bank indicators website. The study is done with yearly data from January 2000 to December 2017. The data is a time-series data that gives a clear picture of the economic development of the nation and impact of the stock market on the economic growth from the early period to the current period. To analyze the result, Descriptive Statistics is used to check the normality and ADF (Augmented Dickey Fuller) Unit Root Test to analyze the Stationarity. Johansen Co-integration test is being used to examine the relationship or Co-integration among the variables.

\section{Data Analysis and Interpretation}

\section{A. Augmented Dickey - Fuller Test of Macroeconomic Variables and NSE}

Augmented Dickey Fuller Unit root test is used to test the Stationarity among the series or the variables. It comprises Level, Fist Difference and 
Second Difference as intercept and trend, intercepts and none.

\begin{tabular}{|l|c|c|c|c|}
\hline \multirow{2}{*}{ Variables } & \multicolumn{2}{|c|}{ Level } & \multicolumn{2}{c|}{ First Difference } \\
\cline { 2 - 5 } & t-Statistics & *Probability & t-Statistics & *Probability \\
\hline FDI & -2.496984 & 0.3268 & -5.389742 & $0.0002 *$ \\
\hline GDP & -2.662749 & 0.2584 & -3.186967 & $0.0324 *$ \\
\hline Crude Oil & -1.712703 & 0.7176 & -5.353074 & $0.0002 *$ \\
\hline Inflation & -2.745349 & 0.2279 & -7.104458 & $0.0000 *$ \\
\hline Interest Rate & -3.237879 & 0.0984 & -7.507715 & $0.0000 *$ \\
\hline
\end{tabular}

Source: Author's calculation; * Significant at 5\% level

The result of the Augmented Dickey Fuller Test is shown in the above table Unit Root Test is used to ascertain the order of integration among the data. ADF test was applied at level, first difference and Second Difference with the assumptions such as Constant, Intercept and Trend. The null hypothesis of the Unit root was rejected in the Level and it shows that there is no stationarity found among the variables. Hence, the variables are tested at First
H0: There is no stationarity exists between macroeconomic variables and Stock Market.

Johansen Co-Integration Rank Test (Trace) of GDP and NSE

\begin{tabular}{|c|c|c|c|c|}
\hline Hypothesized No of CE & Eigen value & Trace Statistic & Critical Value & Prob \\
\hline None & 0.455282 & 15.49471 & 25.97733 & 0.0509 \\
\hline Atmost 1 & 0.350535 & 10.79017 & 3.841466 & 0.0010 \\
\hline
\end{tabular}

Trace test indicates 2 co-integrating at the 0.05 level

Johansen Co-Integration Rank Test (Maximum Eigen Value) of GDP and NSE

\begin{tabular}{|c|c|c|c|c|}
\hline Hypothesized No of CE & Eigen value & Max Eigen Stat & Critical Value & Prob \\
\hline None & 0.455282 & 14.26460 & 15.18717 & 0.1356 \\
\hline Atmost 1 & 0.350535 & 10.79017 & 3.841466 & 0.0010 \\
\hline
\end{tabular}

Max-eigen value test indicates 2 co-integrating at the 0.05 level

The table indicates the Johansen Co-Integration Trace test which implies that the Critical Value is greater than the Trace Statistic Value. Hence, there is a long run association existing between the variables. The table reveals the maximum Eigen statistics in Johansen Co- Integration which shows that the probability value is greater than 0.05 . Hence, the null hypothesis is rejected. This implies that there is a CoIntegration between the variables GDP and NSE.

H2: Co-integration exists between FDI and stock market performance.

Johansen Co-Integration Rank Test (Trace) of FDI and NSE

\begin{tabular}{|c|c|c|c|c|}
\hline Hypothesized No of CE & Eigen value & Trace Statistic & Critical Value & Prob \\
\hline None & 0.418475 & 15.49471 & 20.52556 & 0.0580 \\
\hline Atmost 1 & 0.243400 & 6.973021 & 3.841466 & 0.0083 \\
\hline
\end{tabular}

Trace test indicates 2 co-integrating at the 0.05 level 
Johansen Co-Integration Rank Test (Maximum Eigen Value) of FDI and NSE

\begin{tabular}{|c|c|c|c|c|}
\hline Hypothesized No of CE & Eigen value & Max Eigen Stat & Critical Value & Prob \\
\hline None & 0.418475 & 13.55254 & 14.26460 & 0.0645 \\
\hline Atmost 1 & 0.243400 & 6.973021 & 3.841466 & 0.0083 \\
\hline
\end{tabular}

Max-eigen value test indicates co-integration at the 0.05 level

The table indicates the Johansen Co-Integration Trace test, which implies that the probability value is greater than 0.05 and the Trace Statistic value is greater than the Critical Value. Hence, the null hypothesis is accepted. Similarly, in maximum Eigen statistics in Johansen Co-Integration, the critical value is greater than the maximum Eigen value and the probability value is greater than 0.05 . Hence, the null hypothesis is accepted. This implies that there is Co-Integration between the variables CNX Nifty and Foreign Direct Investment.

H3: Co-integration exists between crude oil price and the stock market.

Johansen Co-Integration Rank Test (Trace) of Crude Oil and NSE

\begin{tabular}{|c|c|c|c|c|}
\hline Hypothesized No of CE & Eigen value & Trace Statistic & Critical Value & Prob \\
\hline None & 0.454946 & 15.49471 & 23.53943 & 0.0525 \\
\hline Atmost 1 & 0.284451 & 8.367646 & 3.841466 & 0.0038 \\
\hline
\end{tabular}

Trace test indicates 2 co-integrating at the 0.05 level

Johansen Co-Integration Rank Test (Maximum Eigen Value) of Crude Oil and NSE

\begin{tabular}{|c|c|c|c|c|}
\hline Hypothesized No of CE & Eigen value & Max Eigen Stat & Critical Value & Prob \\
\hline None & 0.454946 & 14.26460 & 15.17178 & 0.1258 \\
\hline Atmost 1 & 0.284451 & 8.367646 & 3.841466 & 0.0038 \\
\hline
\end{tabular}

Max-eigen value test indicates 2 co-integrating at the 0.05 level

The table indicates the Johansen Co-Integration Trace test which shows that the probability value is lesser than 0.05 percent. Hence, the null hypothesis is accepted. The table indicates the maximum Eigen statistics in Johansen Co-Integration which shows that the critical value is greater than the maximum
Eigenvalue. Hence, the null hypothesis is accepted. This implies that there is a Co-Integration between the variables Crude Oil Price and the stock market.

H4: Co-integration exists between inflation and stock market performance.

Johansen Co-Integration Rank Test (Trace) of Inflation and NSE

\begin{tabular}{|c|c|c|c|c|}
\hline Hypothesized No of CE & Eigen value & Trace Statistic & Critical Value & Prob \\
\hline None & 0.593090 & 15.49471 & 31.46279 & 0.0501 \\
\hline Atmost 1 & 0.301869 & 8.983700 & 3.841466 & 0.0027 \\
\hline
\end{tabular}

Trace test indicates 2 co-integrating at the 0.05 level

Johansen Co-Integration Rank Test (Maximum Eigen Value) of Inflation and NSE

\begin{tabular}{|c|c|c|c|c|}
\hline Hypothesized Noof CE & Eigen value & Max Eigen Stat & Critical Value & Prob \\
\hline None & 0.593090 & 14.26460 & 22.47909 & 0.1020 \\
\hline Atmost 1 & 0.301869 & 8.983700 & 3.841466 & 0.0027 \\
\hline
\end{tabular}

Max-eigen value test indicates 2 co-integrating at the 0.05 level

The table indicates the Johansen Co-Integration Trace test, which implies that probability value is lesser than 0.05 and null hypothesis is accepted. Table indicates maximum Eigen statistics in Johansen CoIntegration, which shows that the $\mathrm{p}$-value is greater than 0.05 . Hence, the null hypothesis is accepted. This implies that there is a Co-integration between variables Inflation and Stock market Inflation.

H5: Co-integration exists between the interest rate and stock market. 
Johansen Co-Integration Rank Test (Trace) of Interest Rate and NSE

\begin{tabular}{|c|c|c|c|c|}
\hline Hypothesized No of CE & Eigen value & Trace Statistic & Critical Value & Prob \\
\hline None & 0.491683 & 15.49471 & 27.30234 & 0.0505 \\
\hline Atmost 1 & 0.339952 & 10.38607 & 3.841466 & 0.0013 \\
\hline
\end{tabular}

Trace test indicates 2 co-integrating at the 0.05 level

Johansen Co-Integration Rank Test (Maximum Eigen Value) of Interest Rate and NSE

\begin{tabular}{|c|c|c|c|c|}
\hline Hypothesized No of CE & Eigen value & Max Eigen Stat & Critical Value & Prob \\
\hline None & 0.491683 & 14.26460 & 16.91627 & 0.0686 \\
\hline Atmost 1 & 0.339952 & 10.38607 & 3.841466 & 0.0013 \\
\hline
\end{tabular}

Max-eigenvalue test indicates 2 co-integrating at the 0.05 level

The table indicates the Johansen Co-Integration Trace test, which implies that the critical value is greater than the trace statistic value. So there is the association in the long run. The table indicates the maximum Eigen statistics in Johansen CoIntegration, which shows that the critical value is greater than the maximum Eigen value. This implies that there is a Co-Integration between the variables of Real Interest Rate and the stock market.

\section{Findings}

From the analysis, it is found that macroeconomic variables are associated with stock market performance. From the analysis, it is clear that all the macro-economic factors are liable in the price movement of stocks. Stock market performance is highly dependent on these macro factors. Any fluctuation or changes happening in these macroeconomic factors directly have an impact on stock market performance. Gross Domestic Product, Foreign Direct Investment, Crude Oil Price, Inflation, Interest Rate; all are co-integrated with stock market performance.

\section{Conclusion}

Investors and investment is the essential object for the stock market performance. The study concludes that Gross domestic product, Foreign Direct Investment, Crude oil price, Inflation and Real interest rate have a significant relationship with the NSE stock market for the study period 2000 to 2017. Investors, policymakers and economists must make decisions regarding the regulations of the stock market and their impact on economic growth.

\section{References}

Abdalla, Issam S.A., and Victor Murinde. "Exchange Rate and Stock Price Interactions in Emerging Financial Markets: Evidence on India, Korea, Pakistan, and Philippines." Applied Financial Economics, vol. 7, no. 1, 1997, pp. 25-35.

Acharya, Shankar. Managing External Economic Challenges in the Nineties: Lessons for the Future, 1999.

Acikalin, Sezgin, et al. "Relationship between Stock Markets and Macroeconomic Variables: An Empirical Analysis of the Istanbul Stock Exchange." Investment Management and Financial Innovations, vol. 5, no. 1, 2008, pp. 8-16.

Agrawalla, Raman K. Share Prices and Macroeconomic Variables in India: An Approach to Investigate the Relationship between Stock Markets and Economic Growth, 2005.

Allayannis, George, and James P. Weston. "The Use of Foreign Currency Derivatives and Firm Market Value." Review of Financial Studies, vol. 14, no. 1, 2001, pp. 243-276.

Arfaoui, Mongi, and Ezzeddine Abaoub. "Equity Home Bias Puzzle between Macro-Finance Interface and Risk-Factors Interference." Journal of Applied Research in Finance (JARF), no. 6, 2011, pp. 147-161.

Aylward. Anthony, and Jack Glen. "Some International Evidence on Stock Prices as Leading Indicators of Economic Activity." Applied Financial Economics, vol. 10, no. 1, 2000, pp. 1-14. 
Balke, Nathan S., and Mark E. Wohart. "What Drives Stock Prices? Identifying the Determinants of Stock Price Movements." Southern Economic Journal, vol. 73, no. 1, 2006, pp. 55-78.

Bhattacharya, Basabi, and Jaydeep Mukherjee. "Causal Relationship between Stock Market and Exchange Rate, Foreign Exchange Reserves and Value of Trade Balance: A Case Study for India." Fifth Annual Conference on Money and Finance in the Indian Economy, 2003.

Chakraborty, Indrani. "Capital Inflows during the Post-Liberalisation Period." Economic and Political Weekly, vol. 41, no. 2, 2006.

Chatrath, Arjun, et al. "Stock Prices, Inflation and Output: Evidence from India." Applied Financial Economics, vol. 7, no. 4, 1997, pp. 439-445.

Chellasamy, P. "Depreciation of Indian Currency and Its Impact on Indian Economy." Vidyaniketan Journal of Management and Research, vol. 1, no. 2, 2013, pp. 13-22.

Chen, Nai-Fu, et al. "Economic Forces and Stock Market." Journal of Business, vol. 59, no. 3, 1986, pp. 383-403.

Cheng, Android C.S. "The UK Stock Market and Economic Factors: A New Approach." Journal of Business Finance \& Accounting, Vol. 22, no. 1, 1995, pp. 129-142.

Jones, Charles M., and Gautam Kaul. "Oil and the Stock Markets." The Journal of Finance, vol. 51, no. 2, 1996, pp. 463-491.

Kaur, Parmjit, and Suveera Gill. "Patterns of Corporate Ownership: Evidence from BSE200 Index Companies." Paradigm, vol. 13, no. 2, 2009, pp. 13-28.

Kearney, Adrienne A., and Raymond E. Lombra. "Stock Market Volatility, The News, and Monetary Policy." Journal of Economics and Finance, vol. 28, 2004, pp. 252-259.

Mishra, A.K. "Stock Prices and Exchange Rate Interlinkages in Emerging Financial Markets:
The Indian Perspective." Proceedings of the International Conference on Business and Finance, 2004, pp. 19-57.

Nurudeen, Abu. "Does Stock Market Development Raise Economic Growth? Evidence from Nigeria." The Review of Finance and Banking, vol. 1, no. 1, 2009, pp. 15-26.

Paramati, Sudharshan Reddy, and Rakesh Gupta. "An Empirical Analysis of Stock Market Performance and Economic Growth: Evidence from India." International Research Journal of Finance and Economics, 2011, pp. 133-149.

Patel, Samveg. "The Effect of Macroeconomic Determinants on the Performance of the Indian Stock Market." NMIMS Management Review, vol. XXII, 201, pp. 117-127.

Pethe, Abhay, and Ajit Karnik. "Do Indian Stock Markets Matter? Stock Market Indices and Macro-Economic Variables." Economic and Political Weekly, vol. 35, 2000, pp. 349-356.

Petros, Jecheche. "The Effect of the Stock Exchange on Economic Growth: A Case of the Zimbabwe Stock Exchange." Research in Business and Economics Journal, pp. 1-17.

Pradhan, R.P., et al. "The Impact of Stock Market Development on Inflation and Economic Growth of 16 Asian Countries: A Panel VAR Approach." Applied Econometrics and International Development, vol. 13, no.1, 2013, pp. 204-220.

SharifHossain, M.D., and Khnd. Md. Mostafa Kamal. "Does Stock Market Development Cause Economic Growth? A Time Series Analysis for Bangladesh Economy." International Conference on Applied Economics, 2010.

Sharma, Sanjeet. "Stock Market Development and Economic Growth." Indian Journal of Management Science, vol. 1, no. 1, 2011.

Tang, Hong-Peng, et al. "Stock Market and Economic Growth in Selected Asian Countries." MPRA Paper No. 37649, 2007.

\section{Author Details}

Aditya Prasad Sahoo, Ph. D. Research Scholar, KIIT School of Management, Bhubaneswar, Odisha, India,

Email ID: adityasahoo007@gmail.com 